\title{
A challenging ménage à trois?
}

\section{Tripartism in the International Labour Organisation}

\begin{abstract}
This article explores one of the foundational features of the International Labour Organization (ILO) - tripartism, or in other words, the fact that it is an institution that brings together representatives of Governments, Employers and Workers - in the light of recent events that have threatened the organisation's smooth functioning. Disagreement over the interpretation of a convention within the ILO supervisory bodies has revealed the changing balance of power between Employers and Workers, and potentially signals a need to rethink the basis of tripartism. At the same time, however, tripartism is a fundamental distinguishing feature of the ILO, one that arguably sets it apart from other international bodies, and is essential to both the organisation's mission and the generation of international labour law more generally. This article re-visits the notion of tripartism, examines the problems that its practice within the ILO raises including with regard to issues of representativity and more recent disagreements, as well as the true significance of the current crisis of tripartism and its possible impact for the ILO and international labour law.
\end{abstract}

KEYWORDS: International Labour Organization (ILO) - tripartism - Representativity civil society - crisis - international organisations - supervisory mechanism - right to strike

\section{Introduction}

The International Labour Organization (ILO) is a specialised UN agency that has as central objective improving the conditions of workers worldwide. Considering the enormous human suffering that deficient working conditions cause globally today, this mission is clearly as relevant now as it was in 1919, when the Organisation was founded. It is however widely acknowledged that the ILO is currently operating in a particularly difficult global environment and faces colossal difficulties in achieving its mandate, all the more so as the Organisation's means and scope for action have been considerably reduced by a range of 
external and internal factors. ${ }^{1}$ In particular, and this is the focus of this article, the Organisation is confronting a major institutional challenge in terms of its unique tripartite structure which came to the fore in 2012, and is yet to be resolved. This crisis could dramatically change the future of the ILO and have a significant impact on international labour law and international law more generally. ${ }^{2}$

Tripartism is a particular feature of the ILO entrenched in the Organisation's Constitution that has widely been considered "revolutionary", 3 particularly relative to other international institutions due to the fact that it implies the active participation of non-governmental entities in all aspects of the Organisation's work. This goes beyond simply discussing and adopting international labour standards (ILS) or supervising these once they are adopted. More specifically, since its inception in 1919, the ILO has formally included within its institutional structure not just governmental representatives of its now 185 member states, but also representatives of Employer and Worker organisations from each of these states, in the "most daring approach”. ${ }^{4}$

Tripartism has been widely hailed as the feature setting the ILO apart and providing it with a "unique advantage". ${ }^{5}$ Indeed, tripartism has been described as the "quiddity" of the $\mathrm{ILO}^{6}$ making the ILO "structurally unique". ${ }^{7}$ It is "the very backbone of the ILO”, 8 and is frequently presented as the reason for the ILO’s survival since $1919 .{ }^{9}$ It is often argued by insiders that the participation of non-state actors has been an "undeniable source of vigour"

\footnotetext{
${ }^{1}$ See F. Maupain, The future of the International Labour Organization in the Global Economy (Hart, Oxford, 2013).

${ }^{2}$ Beyond their important influence on domestic law, international labour standards adopted by the ILO are included in diverse ways, in numerous international initiatives such as Free Trade Agreements, investment treaties, or in the International Financial Corporation's standards of performance, for example, and they are also used, along with the ILO supervisory bodies' comments, by international or regional tribunal or bodies, in particular in the area of human rights.

${ }^{3}$ F. Maupain, 'L’OIT, la justice sociale et la mondialisation' (1999) 278 Collected Courses of The Hague Academy of International Law, p. 331.

${ }^{4}$ NGOs have certainly been involved in international governance for quite some time but the ILO has been deemed to be "the most daring of all international organisations in its approach to NGO participation" and its form of governance is unlikely to be replicated (S. Charnovitz, 'Two Centuries of Participation: NGOs and International Governance’ (1997) 18 Michigan Journal of International Law, pp.183, 216 and 283). International organisations with governmental and NGO members include the IUCN/World Conservation Union, the World Tourism Organization (UNWTO) and the Arctic Council.

${ }^{5}$ ILO, Declaration on Social Justice for a Fair Globalisation (2008).

${ }^{6}$ Charnovitz, supra note 4, p. 216.

${ }^{7}$ ILO, Resolution concerning the Strengthening of Tripartism in the Over-all Activities of the International Labour Organisation (1971). Certainly, as Chinkin and Boyle remark, the ILO's structure is so unique that it "makes it difficult to derive wider lessons about its significance for the institutional process of international lawmaking in general” (C. Chinkin and A. Boyle, The Making of International Law (OUP, Oxford, 2007) p. 157).

${ }^{8}$ W.R. Simpson, 'The ILO and Tripartism: Some Reflections' (1994) 117 Monthly Labor Review, p. 41.

${ }^{9}$ C.W. Jenks, The international Protection of Trade Union Freedom (Stevens \& Sons, 1970) p. 513; Maupain, supra note 1, p.3 - also ILO, 1971 resolution, preamble, supra note 7.
} 
for the Organisation, bringing an "element of dynamism”, and providing additional authority to the Organisation's decisions by taking into account a plurality of positions and stakeholders. ${ }^{10}$ Certainly, it is widely portrayed as having provided legitimacy to the actions of the ILO. ${ }^{11}$ At the same time, however, tripartism in the ILO has also attracted a lot of criticism. ${ }^{12}$ Some commentators have argued that the Organisation is "trapped" within its particular governance structure, ${ }^{13}$ while others contend, for example, that tripartism is the reason why ILO conventions have such a low ratification rate. ${ }^{14}$ Or, on a broader level, tripartism is simply not considered to bring dynamism or legitimacy anymore as some commentators describe the Organisation as "stuck in a time-wrap". ${ }^{15}$

There is no doubt that tripartism in the ILO has not had a smooth existence. As Maupain has stated, tensions between tripartism within the ILO and realities outside the ILO have often reached "rupture point". ${ }^{16}$ Tensions between the growing mandate of the ILO and the narrower representativity of the ILO's constituents have for example waxed and waned over the almost 100 years of the Organisation's existence, despite regular attempts to extend representation to other civil society actors beyond workers and employers' organisations. ${ }^{17}$ As Trebilcock has highlighted, however, the ILO is currently facing particularly testing times characterised by an unprecedented absence of consensus between the Organisation's

\footnotetext{
${ }^{10}$ N. Valticos and G.W. Von Potobsky, International Labour Law (Kluwer, Deventer, 1995) p. 35. Also, Jenks, supra note 9, p. 513.

${ }^{11}$ Supra note 1 , p. 7 . What is 'legitimate' is of course very subjective.

${ }^{12}$ As has the concept of tripartism; we will not explore this line of criticism here.

${ }^{13}$ G. Standing, 'The ILO: An Agency for Globalization?' (2008) 39 Development and Change, pp. 379-80.

These debates are by no means new, however. For example, in 1959, Béguin was already writing that "[w]hether or not tripartism still has a contribution to make in enabling the Organisation to "work more effectively" on its future tasks, and whether new interpretations can be given to this form of collaboration are the questions that face [the] ILO as it enters its fifth decade" (B. Béguin, ILO and the tripartite system (Carnegie Endowment for International Peace,1959) p. 33).

${ }^{14}$ A. Peters, 'Dual Democracy', in J. Klabbers, A. Peters, and G. Ulfstein, The Constitutionalization of International Law (OUP, Oxford, 2009) p.321. Not all conventions have low ratification rates however, and this has probably more to do with the controversies concerning the subject matter of ILS than the tripartite nature of the ILO itself. As Langille notes for example, "the ILO is centred upon the most sensitive political nerve of all modern societies - the relationship of markets and politics and the questions of both the virtues and limits of markets. In the ILO this general question is focused upon the most central and most difficult of all markets - the labour market - a market in people, not commodities” (B. Langille, 'The ILO and the New Economy: New Developments' (1999) 15 International Journal of Comparative Labour Law and Industrial Relations, p. 234). Together with the controversy originating from dominant economic thinking surrounding the desirability of regulating labour issues, this makes law-making in this field particularly difficult.

${ }^{15}$ J. Klabbers, 'Marginalised International Organizations: Three Hypotheses Concerning the ILO' in R. Blanpain, U. Liukkunen and C. Yifeng, China and ILO Fundamental Principles and Rights at Work (Kluwer, The Hague, 2014) p. 185.

${ }^{16}$ Supra note 3, p. 336.

${ }^{17}$ This issue of widening representation was already considered in the 1920s when Albert Thomas attempted to give a formal role to cooperatives (M Louis, 'Syndicats contre coopératives? L'OIT et la représentation des acteurs de la société civile’ (2013) 154 Relations internationales p. 25). See also the successive failed attempts by Director-Generals to include broader actors (see below).
} 
constituents, ${ }^{18}$ which crystallized in a unique institutional crisis in June 2012. This concerned a long-standing disagreement - or, rather, an agreement to disagree - between the ILO Employers and Workers' Groups regarding the existence of a right to strike, and was partly legal and partly political, revealing a significant transformation of the balance of power between the two groups. It is moreover extremely telling that this disagreement touches upon an issue which is at the very heart of freedom of association, and which is not without consequences for the future of trade unions, and therefore, tripartism as it is currently operationalised.

To grasp the extent of the possible repercussions of this crisis, this article revisits the central place that tripartism holds in the constitutional landscape of the ILO as well as its operationalisation, which is of course contingent not only on its purpose, but also the broader context within which the Organisation operates. The article begins by clarifying the tripartite institutional structure of the ILO, which is generally not very well known by contemporary international lawyers, ${ }^{19}$ before then determining its influence on the making and supervising of international law within the ILO. It then examines the challenges that tripartism has faced over the years, focusing initially on issues of representativity, before turning to the recent clashes between Employers and Workers in the context of the 2012 crisis regarding the right to strike. It goes on to explores what this crisis potentially means for the ILO and for international labour law and its supervision more generally, before arguing that resolving the current crisis between the Organisation's constituent groups is critical for the future of international labour law, and for the future of the ILO, but will likely require a re-thinking of the nature of tripartism. Unless the ILO can overcome the current crisis of tripartism and make bold decisions, it will struggle to remain relevant and effectively implement its mandate to improve workers' conditions worldwide, despite its continuing $21^{\text {st }}$ century relevance. ${ }^{20}$

\footnotetext{
${ }^{18}$ A. Trebilcock, 'Putting the record straight about international labor standard setting' (2010) 31 Comparative labor law and policy journal pp. 566-567.

${ }^{19}$ The ILO and tripartism are rarely mentioned in any depth, even in studies concerning non-state actors and international law (e.g. J. D’Aspremont (ed.) Participants in the International Legal System - Multiple perspectives on non-state actors in international law (Routledge, London, 2011); A Peters et al., Non-State Actors as Standard Setters (CUP, Cambridge, 2009). See however, G. Nolte and S. Lagodinsky, 'The Role of Non-Governmental Organizations in the International Labor Organization', in E. Benvenisti and G. Nolte (eds.) The Welfare State, Globalization, and International Law (Springer, 2004). Some have compared ILO’s tripartism with the EU's social dialogue however (e.g. F. Milman-Sivan 'Representativity, Civil Society, and the EU Social Dialogue: Lessons from the International Labour Organization’ (2009) 16 Indiana Journal of Global Legal Studies; T. Novitz and P. Sypris 'Assessing Legitimate Structures for the Making of Transnational Labour Law: The Durability of Corporatism’ (2006) 35 Industrial Law Journal, pp. 367-394).

${ }^{20}$ This article draws on primary and secondary written material, but also on oral interviews conducted between February and August 2014 with individuals from the ITUC, national confederations, the ILO (ACTRAV,
} 


\section{Tripartism in the ILO}

In order to situate the difficult operationalisation of tripartism, it is important to remember the context in which tripartism was established. By and large, tripartism did not exist at the national level in 1919, and its genesis is very much associated with the founding of the ILO. ${ }^{21}$ The instability that prevailed at the time of the creation of the ILO - with, in addition to the resilience of the Bolshevik Revolution, labour strikes all over Europe, including in Switzerland and the Netherlands which had not been devastated by the recent war - meant that "there could be no question of giving labor representatives merely a consultative and preparatory role in the projected organization for international labor legislation”. ${ }^{22}$ In order to create an organisation which might credibly provide an answer to Bolshevism and be an alternative to revolution - or, even more bluntly, an "insurance against revolution"23 - it needed to include workers and provide them with a voice; ${ }^{24}$ hence the constitutionalisation of tripartism.

Tripartism is established in the ILO's Constitution which, with other texts, details meticulously how Members of the ILO will be represented and will participate in the Organisation. However, as stated by the McNair Committee in 1956, in charge of examining the question of the independence of organisations, there is "no official exposition of the principles underlying the tripartite structure of the ILO”. ${ }^{25}$ It was clear to the authors of this report, though, that the objective of tripartism was, at the time, "to enable the workers and the

ACTEMP, as well as current and retired civil servants), and Workers’ organisations. Individual interviewees are not identified but indications are given where specific insights from these interviews have been taken.

${ }^{21}$ J. Van Daele, 'Engineering Social Peace, Peace: Networks, Ideas, and the Founding of the International Labour Organization’ (2005) 50 International Review of Social History p. 466. Tripartism existed only in England and France (T. Landelius, Workers, Employers and Governments: A Comparative Study of Delegations and Groups at the International Labour Conference, 1919-1964 (Norstedt \& Söner, 1965) p. 21). More generally, tripartism is attributed to Phelan, who believed that only an organisation which had the backing of all interested parties would deliver results (ILO, Edward Phelan and the ILO (ILO, Geneva, 2009) pp.18 and 141). On the history of tripartism, see A.K. Tikriti, Tripartism and the International Labour Organisation - A Study of the Legal Concept: Its origins, Function and Evolution in the Law of Nations (Almqvist and Wiksell, Stockholm, 1982), pp.16-125 and 334-337.

${ }^{22}$ Béguin, supra note 13, p. 5.

${ }^{23}$ D. Maul, Human Rights, Development and Decolonization: The International Labour Organization, 1940-70 (Palgrave and ILO, Geneva, 2012) p. 2. Also B. Cabanes, The Great War and the Origins of Humanitarianism 1918-1924 (CUP, Cambridge, 2014) p. 79; and R.W. Cox, 'ILO: A Limited Monarchy', in R.W. Cox and H.K. Jacobson (eds.) Anatomy of influence; decision making in international organization (Yale University Press, Yale and London, 1973), p. 102.

${ }^{24}$ L. Helfer, 'Understanding Change in International Organizations: Globalization and Innovation in the ILO' 2006 Vanderbilt Law Review p. 679, referring to Robert Cox (supra note 23, p. 102). Also Béguin, supra note 13 , p. 6. As is well known, it is, with the help of visionaries, the combination of the industrial revolution in the $19^{\text {th }}$ century - which had led to the proliferation of abysmal working conditions - the ravages of the First World War and the rise of Bolshevism that led to the ILO's creation.

${ }^{25}$ ILO, Committee on Freedom of Employers' and Workers’' Organisations, GB.131/7/8, 1956, para. 9. 
employers to exercise their own influence upon, and make their own contributions to, the discussions of industrial matters". ${ }^{26}$ With this in mind, tripartism has been embedded in every aspect of the Organisation's institutional structure and in order to better grasp the present state and operationalisation of tripartism in the ILO, an overview of how tripartism influences this structure both in terms of process and outputs is essential.

\section{A. The ILO's Institutional Structure}

The ILO is made up of three entities, two of which are tripartite: the Governing Body and the International Labour Conference (ILC). The third entity, the International Labour Office (Office), is a secretariat of civil servants.

The Governing Body is composed of 28 government members, ${ }^{27} 14$ employer members, and 14 worker members. ${ }^{28}$ Government members, representing their own national Governments, are elected by the Government delegates to the ILC (Article 7(2), Constitution), while employers and workers' members, representing their groups, are elected by their respective groups at the ILC (Article 7(4)). This latter provision contributes to the autonomy of the non-governmental members. ${ }^{29}$ The Governing Body meets three times a year and has important functions, which include appointing the Director-General who carries out his ${ }^{30}$ functions according to its instructions (Article 8(1)), directing the Office's activities (Article 10), deciding the agenda of the ILC (Article 14(1)) as well as several important matters concerning the supervision of ILS. ${ }^{31}$ Decisions on all these matters are usually adopted by consensus. $^{32}$ If consensus cannot be reached, each member of the Governing Body has one vote, meaning that that the governments/employers/workers voting ratio is 2/1/1 in plenary sessions. ${ }^{33}$ When decisions are adopted within committees appointed by the

\footnotetext{
${ }^{26}$ Ibid.

${ }^{27}$ Ten of these are "States of chief industrial importance" which are automatically Governing Body members Art 7(1) - currently Brazil, China, France, Germany, India, Italy, Japan, the Russian Federation, the United Kingdom and the United States. An amendment adopted by the ILC in 1986 abolishing this stipulation has not received the necessary ratifications to come into force.

${ }^{28}$ Section 1.1.1, Standing Orders of the Governing Body. There are also 66 deputy members (28 Government members, 19 Employers members and 19 Workers members).

${ }^{29}$ Jenks, supra note 9, p. 70.

${ }^{30}$ The ILO is yet to have a female Director-General.

${ }^{31}$ For a full list of duties, see ILO, Compendium of rules applicable to the Governing Body of the International Labour Office (ILO, Geneva, 2011), paras. 5-6.

32 'Consensus' in the Governing Body means an "established practice under which every effort is made to reach without vote an agreement that is generally accepted” (ibid, para.46).

33 This 2/1/1 representation is to avoid that Government representatives are outvoted by the Workers or the Employers.
} 
Governing Body, however, representatives of Governments, Employers and Workers are equally represented and have an equal number of votes (i.e. on a 1/1/1 basis). ${ }^{34}$

The ILC, for its part, is a forum for tripartite discussions which every year brings together delegations from each member state of the ILO consisting of two Government delegates, one Employer delegate and one “workpeople” delegate (Article 3(1), Constitution). The process of nominating non-Government delegates to the ILC is obviously fundamental to the functioning of tripartism. It is governed by Article 3(5) of the Constitution which establishes the obligation for Members of the ILO to "undertake to nominate non-Government delegates and advisers chosen in agreement with the industrial organizations, if such organizations exist, which are most representative of employers or workpeople, as the case may be, in their respective countries". This article has been interpreted by the Permanent Court of International Justice (PCIJ) in an advisory opinion of $1922^{35}$ that still guides the ILC's tripartite Credentials Committee in charge of scrutinising nominations. ${ }^{36}$ While this Committee is very much solicited, only nominations of the workers' delegate of Myanmar have been invalidated so far; ${ }^{37}$ although the Credential Committee bears in mind the principles of freedom of association, as will be examined, the emphasis is on universality.

During the ILC, the tripartite representatives discuss ${ }^{38}$ and adopt ILO instruments (conventions, protocols, declarations, recommendations and resolutions), discuss policies, adopt the Organisation's programme and budget, and elect the Governing Body, for example. The ILC involves large numbers; 5,250 individuals, including delegates and advisors, formed part of the delegations of the 165 Member States that participated in the ILC in 2014, for

\footnotetext{
${ }^{34}$ Section 4.2.3, Standing Orders of the Governing Body. Such Committees, which used to be quite numerous, have almost all been eliminated following reforms adopted in 2011 (see ILO GB.310/9/1, para.10 and GB.310/PV, para.129) - according to Diller, these reforms have been instigated by Governments who favoured plenary decision-making since they have a greater voting power (J. Diller, 'Taking Account of Human Values in the International Economic Legal Order: Law and the Legal Counsel of the International Labour Organisation', in A. Qureshi (ed.) The Role and Contribution of Legal Counsels to the Development of International Economic Law (Kluwer Law International, 2012).

${ }^{35}$ PCIJ, Designation of the Workers' Delegate for the Netherlands at the Third Session of the International Labour Conference, Advisory Opinion, 31 July 1922, p. 19 (in particular, pp. 23 and 25).

${ }^{36}$ This Committee may, "by two-thirds of the votes cast by the delegates present, refuse to admit any delegate or adviser whom it deems not to have been nominated in accordance with this article" (Article 3(9) Constitution).

${ }^{37}$ See information on the ILO website (http://www.ilo.org/dyn/creds/credsbrowse.home?p_lang=en). For more details of the Credential Committee, see Diller, 2012, supra note 34. For a historical perspective, see Van der Kooy, 'What is the Substance of Tripartism in the ILO?' (1977) 8 Nehterlands. Yearbook of International Law p. 3. For a perspective on its changing role in light of recent amendments to its mandate, see F. Milman-Sivan, 'Freedom of Association in Deliberative Spaces: the ILO Credentials Committee' in A. Blackett and A. Trebilcock (eds.), Research Handbook on Transnational Labour Law (Edgar Elgar, forthcoming, 2015).

${ }^{38}$ In the ILO, the adoption of an instrument does not follow a period of 'negotiations' but rather, of ‘discussions' (Valticos and Von Potobsky, supra note 10, p. 50).
} 
example. $^{39}$ Traditionally, the ILC lasted 3 weeks, but starting from 2015, its length has been reduced to 2 weeks, something that must have been welcomed by Governments, as they bear the financial responsibility for their delegation (Article 13(2)a)), as well as by most delegates in view of the constraints spending three weeks in Geneva entailed - this measure may thus improve the quality of the delegations. At the same time, this reduction might also cut social dialogue short and make its exercise less meaningful. ${ }^{40}$ The ILC takes place in plenary sessions, where each delegate has the right to vote individually (on a 2/1/1 basis - Article 4(1)) and in Committees (either standing Committees, or technical Committees, in charge for example of the elaboration of ILS), where each group has an equal vote (on a 1/1/1 basis). ${ }^{41}$ This latter deviation, which we find in the Governing Body as well, is the result of an internal custom of the Organisation, ${ }^{42}$ and gives more weight to Employers and Workers as the decisions of these committees are adopted normally without modification by the ILC.

Discussions take place within the groups behind closed doors and a united front is normally presented in public and recorded in the proceedings; similarly, most negotiations between the groups take place behind closed doors ${ }^{43}$ and are later staged for the record. While Government representatives do not form a homogenous group and are more likely to vote according to their region, ${ }^{44}$ Employers and Workers' groups have been compared to political parties, as delegates vote according to their group rather than their nationality. ${ }^{45}$ The International Trade Union Confederation (ITUC) and the International Organisation for Employers (IOE) provide secretarial support to, respectively, the Workers and Employers' groups, and have a key role in formulating the groups' responses at the Governing Body and the ILC. They work in close collaboration with, respectively, the bureau of Workers' Activities (ACTRAV) and of Employers’ Activities (ACT/EMP) within the Office.

\footnotetext{
${ }^{39}$ ILO, Second Report of the Credential Committee, 103rd Session, 2014 - as compared to 1746 in 1981.

${ }^{40}$ Indeed, as has been recognised by the ILO itself, social dialogue takes time and shortcuts are not desirable.

${ }^{41}$ There are two exceptions, the Finance Committee which is composed only of Governments, and the Selection Committee. On votes at the ILC, see generally Tikriti, supra note 21, p. 156, and H.G. Bartolomei de la Cruz et al., International Labor Organization: the international standards system and basic human rights (Westview, 1996) p. 7.

${ }^{42}$ W. C. Jenks, 'The Significance for International Law of the Tripartite Character of the International Labour Organisation' 22 Transactions of the Grotius Society (1936) pp. 45-81.

${ }^{43}$ Tikriti, supra note 21, p. 155. This is still the case today. As Cox further points out, "[i]n ILO practice few decisions occur as a result of one actor's making a proposal that is first debated, then accepted or rejected by the other decision makers. The origin of most initiatives is very complex and rarely apparent from the public record. A tradition of building consensus has been carefully cultivated, and the process consists of many initial informal stages in the gathering of support for a new proposal. The informal network of influentials manages the process of forming a consensus; and generally overexposure as an initiator breeds failure" (Cox, supra note 23, p. 127).

${ }^{44}$ Asia and Pacific (ASPAG), Africa, Latin American and Caribbean Group (GRULAC), and the industrialized market economy countries (IMEC).

${ }^{45}$ Jenks, supra note 42, 46-47 and note 9, pp. 515-517 - this balances the fact that there are more Governments' representatives.
} 
The third component of the ILO, the International Labour Office, is not tripartite. Its officials, who are appointed by the Director General, are "exclusively international in character [and they] should not seek or receive any instructions from any governments or from any other authority external to the Organisation” (Article 9(4), Constitution). Their functions include collecting and distributing information, studying issues for the adoption of ILS by the ILC and, importantly, carrying out technical assistance, in particular with regards to national labour law reforms (Article 10). Albert Thomas, the first Director General of the ILO, and Georges Scelle were however convinced that the Office had a crucial - even vital role as an arbitrator, a researcher, an idea provider, ${ }^{46}$ even as an advocate for the workers, ${ }^{47}$ and its role - and that of the Director-General - has clearly expanded since the ILO's inception, ${ }^{48}$ to the extent that both have even been credited for the ILO's survival so far. ${ }^{49}$ Certainly, Maupain argued in 1999 that the Office goes beyond the most basic common denominator when it makes suggestions to the Conference or the Governing Body, and that its role is to help overcome oppositions between different interest groups within the representative organs. ${ }^{50}$ The role of the Office has changed in this regard, however, and it has become very cautious - some would say more passive ${ }^{51}$ - in recent years. This has been further coupled with a deprofessionalisation of civil servants within the office. ${ }^{52}$ This has of course important consequences for the ILO, as we will see in the last part of the article. More generally however - although this has always been the case - it is clear that both Workers

\footnotetext{
${ }^{46}$ See the works of Albert Thomas and Georges Scelle, cited in Maupain, supra note 3, p. 364. Also, Jenks, supra note 9, pp. 517-518

${ }^{47}$ Maupain, ibid., p. 366. Thomas justified his role by arguing that the Organisation had been created "for the workers and to improve their conditions” (E. Phelan, Yes and Albert Thomas (Columbia University Press, 1936) 246).

${ }^{48}$ See Cox's account (supra note 23) and Jenks, supra note 9, pp. 517-518 - Jenks explains that it is precisely because he was elected by the combined votes of Employers and Workers that Albert Thomas was able to act the way he did.

${ }^{49}$ Helfer, supra note 24, pp. 681 et seq.

${ }^{50}$ Maupain, supra note 3, pp. 365-366. The Office usually makes suggestions to add items on the agenda (E. Hass, Beyond the Nation-State - Functionalism and International Organization (ECPR Press, 2008 - first published in 1964) p. 213). The role that Phelan had in drafting the Declaration of Philadelphia, and the role that Maupain had regarding the 1998 and 2008 Declarations are well known, for example.

${ }^{51}$ As Maupain states, the "tripartite compromise" or the "excess of tripartite zeal" of the Office raises the "risk ... that in anticipation of negative reaction from one group or another, certain topics might be given up completely, or that controversial conclusions might be emasculated" (supra note 1, p. 122).

${ }^{52}$ See Standing, supra note 13, pp. 372-373 and G. Rodgers, et al., The ILO and the quest for Social Justice (ILO, 2009) p. 234. The problems raised are not unique to the ILO, however, as is well highlighted by the fact that the WHO's field offices in Africa have been starkly exposed not to be "staffed with the most capable people but with political appointees" during the recent Ebola crisis - see http://www.theguardian.com/world/2014/oct/04/ebola-zaire-peter-piot-outbreak.
} 
and Employers wish that the Office was less "neutral" and more representative of their groups. $^{53}$

\section{B. Tripartism and ILS}

Tripartism has a huge influence on international labour standards (ILS), which makes the current crisis particularly alarming. It intervenes at several levels, including at the stage of exploration of a topic and its suitability for standard setting, during discussions as to the content and wording of a standard, its adoption, and its supervision and implementation. Each of these stages involves the reaching of a consensus between the tripartite groups as well as voting. This obviously has an impact on the ILS adopted. ${ }^{54}$

The ILO has been very prolific in terms of ILS, the ILC having adopted a very large number of instruments since 1919: 189 conventions and 203 recommendations on a range of different issues, of which 67 and 83 respectively, as well as six protocols, are considered upto-date today. ${ }^{55}$ ILS keep on being adopted - including, for example, the very important Maritime Labour Convention (MLC) in 2006 and Convention No. 189 on Domestic Workers in 2011 - and they keep on being ratified - 23 ratifications were registered between April and September 2014, for example. ${ }^{56}$

First and foremost, the elaboration and adoption of ILS involve several steps and each of these involves Employer, Worker and Government representatives. After a topic for standard setting is suggested to the Governing body, ${ }^{57}$ it is discussed and a decision is taken, through agreement or by vote, whether to place it on the agenda of the ILC. ${ }^{58}$ Once this has been decided, a two year process normally takes place $^{59}$ before the final draft of a convention or recommendation is discussed in the ILC and put to a vote for its adoption. This process

\footnotetext{
${ }^{53}$ See Maupain, supra note 3, pp. 365-66; ILO, Rec. of Proc. No7, 2013, 7/2 (for the Employers’ view). Information also obtained from interviews.

${ }^{54}$ Many criticism of the ILO relating to the fact that its ILS are not relevant to current issues (e.g. Klabbers, supra note 15, pp. 185-186 - who does admit that this is not true of all ILS) should take into account this particular feature of tripartism which is both an obvious strength and weakness.

${ }^{55}$ In January 2015. These numbers drop even more if we take into account the coming into force of the Maritime Labour Convention. The ratification of all up to date conventions is promoted by the ILO.

56 This includes ratifications by Ireland which has ratified the MLC and Convention No.189, and Kenya and Belize, which have ratified the MLC, but also Switzerland which has ratified Convention No. 183 on maternity leave, or Mauritius, Convention No. 155. See latest ratifications in NORMLEX (ILO website).

${ }^{57}$ Article 14(1), Constitution, states that the agenda of the Conference is "settled by the Governing Body, which shall consider any suggestion as to the agenda that may be made by the government of any of the Members or by any representative [employers' or workers'] organization ... or by any public international organization”. 58 See Articles 34 and 35, Standing Orders of the Conference, for complete details.

${ }^{59}$ A single-discussion procedure is also possible - Art 38, Standing Orders of the Conference; see also ILO, Handbook of procedures relating to international labour Conventions and Recommendations (ILO, Geneva, 2012) para. 2.
} 
involves Governments, Employers and Workers; the latter two being consulted, ${ }^{60}$ and their replies, with those of Governments, are used by the Office to draft the instrument.

In order to avoid an instrument being adopted by one group only, a draft needs two-thirds of the votes cast by the delegates present at the ILC to be adopted (Article 19(2)) - this is to ensure that Workers and Employers cannot, on their own, adopt an instrument without the support of Governments - and a quorum needs to be reached (Article 17(3)). The quorum was almost not reached when the Declaration on Fundamental Principles and Rights was adopted in 1998, testifying to the difficult discussions which preceded its adoption. ${ }^{61}$ Generally, it is quite unusual for a draft not to be adopted considering that ILS reflect extended discussions, concessions, and compromises made by the three groups. ${ }^{62}$ They are moreover generally quite broad. This does not mean that the adoption of ILS always gains the support of all three groups, however. The adoption of Convention No. 175 on Part Time Work was for example overwhelmingly rejected by employers. ${ }^{63} \mathrm{~A}$ Recommendation on the Employment relationship was adopted in 2006 but was also opposed by employers - out of the 94 negative votes, all were from employers ${ }^{64}$ - while most of the abstentions and the votes against Convention No. 189 on Domestic Workers were also by employers. ${ }^{65}$ This is not a recent trend - the adoption of Convention No. 100 on Equal Remuneration, now a fundamental convention with 171 ratifications, was not supported by employers. ${ }^{66}$ Having said this, employers do take the initiative for some ILS - discussions on the topic of formalising the

\footnotetext{
${ }^{60}$ These consultations were added to the Standing Orders in 1987 - they were recommended by art 2(f) of resolution of 1971 and Convention No. 144 on Tripartite Consultation (International Labour Standards) of 1976 makes them compulsory (138 States had ratified this ‘governance convention’ in January 2015).

${ }^{61}$ The 1998 discussions, which dealt with the social clause, revealed North/South divisions. Only affirmative and negative votes are included in the quorum (Art 20(1), Standing Orders of the Conference). The quorum was not reached when a convention on fishers was put to the vote in 2005 - the Employers explained that they abstained because they did not want the ILO to be a "graveyard of [unratified] standards" (ILO, Rec. of Proc., 2005, 25/3 and 25/24).

${ }^{62}$ An important exception to this is the discussion that took place in 1997 and 1998 in view of adopting an instrument on the theme of contract labour (workers dependant on an employer but not defined as employees) which was abandoned because of Employers' resistance or, in their own words, "implacable opposition to the adoption of any instrument on the subject of contract labour” (ILO, Records of Proceedings (ILC 1998) 16/3). 63 ILO, Rec of Proc, 1994, 28/20. Convention No. 177 on Home Work similarly did not get the support of employers, who in this case even withdrew from the discussions about the instrument (See L. Vosko, Standard Setting at the International Labour Organization: the Case of Precarious Employment, in J.J. Kirton and M.J. Trebilcock (eds), Hard Choices, Soft Law: Voluntary Standards in Global Trade, Environment and Social Governance (Ashgate, 2004) p. 140).

${ }^{64}$ ILO, Record of Proceedings, 2006.

65 ILO, Record of Proceedings, 2011, 30/42-47.

${ }^{66}$ Out of the 33 delegates who voted against the adoption of this Convention, 31 were Employers' delegates (ILO, Record of Proceedings, 1951, 447).
} 
informal economy were initiated by Employers in 2012, ${ }^{67}$ for example - and the adoption of other ILS has been easier, including for example, Convention No. 29 on Forced Labour, Convention No. 87 on Freedom of Association, Convention No. 111 on Discrimination, and Convention No. 182 on the Worst Forms of Child Labour - the latter was in fact adopted by unanimity.

The tripartite nature of conventions has important effects on the application of international treaty law. ${ }^{68}$ Although States remain responsible for ratification, ${ }^{69}$ they may not make reservations upon ratification, for example, as conventions are adopted by the tripartite ILC and not by individual States. ${ }^{70}$ Furthermore, while States are responsible for the enforcement of conventions (Article 19(d), Constitution) and the application of recommendations, the enforcement of many ILS relies explicitly on the participation of Employers and Workers. ${ }^{71}$

Furthermore, many aspects of the ILS supervisory mechanisms are tripartite in nature or have involved tripartite decision making. ${ }^{72}$ This is particularly the case of the Committee of Experts on the Application of Conventions and Recommendations (CEACR), which independent legal experts are appointed by the tripartite ILO Governing Body based on proposals put forward by the Office, the tripartite Committee on the Application of Standards (CAS) of the ILC, and the tripartite Committee on Freedom of Association (CFA), which is made up of representatives nominated by each group and is chaired by a neutral academic,

\footnotetext{
${ }^{67}$ The aim of this recommendation may not be to enhance the protection of workers' rights however - see La Hovary, 'The ILO and the Informal Economy: A Legal Perspective' (2014) International Journal of Comparative Labour Law and Industrial Relations.

${ }^{68}$ For example, Jenks, supra note 42; Valticos and Von Potobsky, supra note 10, pp. 50-51.

${ }^{69}$ Although Article 5 of Convention No. 144 on Tripartite Consultations requires consultations with employers and workers organisations at appropriate intervals in this regard.

${ }^{70}$ Jenks, supra note 42, pp. 58-61. This was established and communicated to member States in 1920. See also

E. Osieke, Constitutional law and practice in the International Labour Organisation (Martinus Nijhoff, Dordrecht, 1985) pp. 154-56; and G Raimondi., 'Réserves et conventions internationales du travail' in J-C. Javillier, B. Gernigon and G. Politakis (eds.), Les normes internationales du travail: un patrimoine pour l'avenir - Mélanges en l'honneur de Nicolas Valticos (ILO, Geneva, 2004) pp. 531-33. Of course, ILS have adapted as a result and most allow for flexibility (ibid., pp. 535-37).

${ }^{71}$ E.g. Convention No. 131 on Minimum Wage Fixing provides that the authorities shall determine the group of wage earners covered "in agreement or after full consultation with the representative organisations of employers and workers concerned" and shall create or maintain a minimum wage setting machinery in consultation with these organisations, and, if appropriate, with their participation.

${ }^{72}$ The ILO supervisory system has been described extensively - see e.g., F. Maupain, 'The Settlement of Disputes within the International Labour Office' (1999) 2 Journal of International Economic Law, pp. 273-93; J-M. Servais, International Labour Law (Kluwer Law International 2011); N. Valticos, 'Once More about the ILO System of Supervision: In What Way is it Still a Compliance Model?’ in N. M. Blokker and S. Muller (eds.), Towards More Effective Supervision by International Organizations: Essays in Honour of Henry G. Schermers (Vol. I) (Martinus Nijhoff, Dordrecht, 1994).
} 
with all members approved by the Governing Body. These have all been affected by the current crisis of tripartism, examined in the last part of this article.

The CEACR, an independent body, was created in 1926 along with the CAS by the tripartite ILC. It examines once a year reports from Governments containing information requested by the Governing Body on the measures that they have taken to apply, in law an in practice, ratified conventions (Article 22, Constitution). These need to have been communicated to the most representative organisations of Workers and Employers (Article 23). When the CEACR notes violations of the ratified convention, it makes an observation or direct request to that effect, taking all the comments that it has received into account and giving them visibility. As the number of ratifications has increased over the years - they were 7,962 in October 2014 - the involvement of workers and employers in the work of the CEACR has also increased, and in 2014, the CEACR receive 1,001 'Article 23' comments, 298 from employers' organizations and 703 from workers' organizations. ${ }^{73}$ The CEACR also drafts a General Survey, on a topic decided by the Governing Body, which concerns the application of certain instruments in all the ILO’s member states.

The CFA (a Governing Body committee) and the CAS (an ILC committee) on the other hand, are tripartite in their structure. The CAS' task is to examine the work of the CEACR. More specifically, as non-compliance is rampant and the CEACR's report is thus much too voluminous, it examines a "special list" of cases of worst violations and reaches recommendations - normally by consensus - after the Governments of countries associated with the list of cases had the opportunity to explain their national situation. Cases related specifically to violation of the principles of freedom of association, are brought to the CFA's attention by any Employers' or a Workers' organisations - and this, whether the State concerned has ratified or not the relevant conventions as the principle of freedom of association is included, along with other principles, in the Constitution. Cases are discussed amongst the 9 members of the CFA who include 3 members of each constituents' group. Conclusions are (normally) reached by consensus, giving them more weight. This very important body has developed the meaning of freedom of association and collective

\footnotetext{
${ }^{73}$ ILO, CEACR 2014, General Report, para.86. There has not necessarily been a corresponding increase in the quality of these reports - something that can also be said of Government reports (B. Creighton 'The Future of Labour Law: Is there a role for International Labour Standards?' in C. Barnard et al. (eds) The Future of Labour Law (Hart, 2004) p. 262).
} 
bargaining in practice through its extensive case law. It is dealing with an increasing number of complaints.

Further supervisory procedures provide an opportunity for Employers and Workers' organisations to make representations, and States, delegates to the ILC or the Governing Body to make complaints, regarding the failure to give effect to conventions (Article 24 and 26, Constitution). Both of these procedures, which may involve the setting up of a tripartite Commission of Enquiry, have not been used as much as it was initially hoped when the ILO was founded, and the "regular" supervision by the CEACR and the CAS has become de facto the central part of the ILO supervisory system and the one which has the most visibility outside the $\mathrm{ILO}^{74}$ (particularly, the CEACR which, in verifying application of conventions, clarifies their meaning - this function has triggered the present crisis).

\section{Challenges to tripartism}

Maintaining some equilibrium or some common ground in the desires of the tripartite representatives is obviously extremely important to meeting the ILO's objectives, including moving towards the achievement of social justice. This has always been a challenge for the Organisation. Tripartism within the ILO is protected by the Constitution and has been somewhat more "immune" to the changes affecting national industrial relations; changes in the balance of power between employers and workers has inevitably affected the ILO's work, however. $^{75}$

During the XXth century, significant tensions emerged in the ILO between tripartism within the ILO, (whereby each delegate has an independent vote), and the national reality of tripartism - or rather, its absence when there are no independent organisations. Very serious tensions arose specifically because organisations, and therefore their delegates, were not independent. This was for example the case of Worker delegates under fascism (when there was no freedom of association), or Employer and Worker delegates under communism (when private employers were non-existent and the state represented the interests of workers). ${ }^{76}$ Difficulties also arose with the huge membership increase following decolonisation, as many

\footnotetext{
${ }^{74}$ See F. Maupain ‘The ILO Regular Supervisory System: A Model in Crisis?’(2013) 10:1, International Organisations Law Review, pp. 117-175.

${ }^{75}$ W. Sengenberger, The International Labour Organization - Goals, Functions and Political Impact (Friedrich Ebert Stiftung 2013) p. 60.

${ }^{76}$ This resulted in the refusal of the majority of the Employers' Group to elect representatives of the employers of socialist countries to the Governing Body (V-Y. Ghebali, The International Labour Organisation: a case study on the evolution of U.N. specialised agencies (Martinus Nijhoff, 1988) p. 28). This was resolved by the ‘Ago formula’ (see Haas, supra note 50, p. 215).
} 
Employers and Workers' representatives were controlled by the Governments. ${ }^{77}$ Despite the serious tensions surrounding the ILO's fundamental principle of freedom of association that these situations raised, demanding the existence of independent organisations in all of these cases was deemed to de facto exclude the nomination of delegates from a significant number of countries, creating a situation which would have been contrary to the principle of universality of the ILO. ${ }^{78}$ Furthermore, since 1919, the demand for tripartism within the ILO has been seen as a means of promoting tripartism and freedom of association within countries. ${ }^{79}$ Having said this, the challenges faced by the ILO today seem to have become more complex, and the relations between its tripartite constituent groups have evolved.

\section{A. A changing workforce and a multiplicity of employers}

Representation in the ILO is of course limited to Governments and Workers and Employers' organisations, excluding all those who are not part of these three institutions. Representation is further limited by the fact that these groups do not properly capture the voice of all those they claim to represent and that they do not have the same control over labour issues as in the past. This obviously includes States, ${ }^{80}$ but there also exists a widespread critique of the current representativity of Workers and Employers' groups since the end of the Cold War, and some have remarked that the nature of stakeholders in the ILO has changed over time. ${ }^{81}$ More fundamentally, current developments in the world of work are seen as "threaten[ing] to explode the tripartite categories”. ${ }^{82}$

More specifically, it is clear that neither group can realistically represent the fragmented and conflicting interests of all workers or all employers, and both are said to represent only their members and their interests. This is perhaps most obvious in relation to workers' representation, which is realised through trade unions, as this means that de facto,

\footnotetext{
${ }^{77}$ Maul, supra note 23 (in particular, pp. 278-85).

${ }^{78}$ For thorough survey of these issues, see Tikriti, supra note 21, pp. 339-346; Maupain, supra note 3, pp. 333344.

${ }^{79}$ E.g. J-M Bonvin, L'Organisation internationale du Travail: étude sur une agence productrice de normes (PUF, Paris, 1998) pp. 68-69. The role of the ILO is still very much seen in this way today. It should be recalled that fundamental Convention No. 87 on Freedom of Association and the Right to Organise establishes that all workers and employers shall have the right to establish and to join organisations of their choice.

${ }^{80}$ See e.g. Peters, supra note 14, for a discussion of democracy in international law.

${ }^{81}$ S. Charnovitz, 'Nongovernmental Organizations and International Law' (2006) 100 American Journal of International law, p. 363.

${ }^{82}$ Maupain, supra note 1, p. 10. Generally, see B. Hepple, Labour Laws and Global Trade (Hart 2005) pp. 5354; S Cooney, 'Testing Times for the ILO: Institutional Reform for the New International Political Economy', Com Lab. L. \& Policy Journal, vol. 20, n 3, 1999, pp. 370-373.
} 
unorganised workers do not have a formal voice in the ILO, ${ }^{83}$ despite the fact that all workers are of concern to the ILO, and Workers' delegates should represent all workers, according to the PCIJ. ${ }^{84}$ An additional reality is the fact that representatives of Workers' organisations come from national confederations that do not necessarily have much control over their members. ${ }^{85}$ Moreover, as is well known, despite some positive examples, trade unions worldwide are generally either not gaining or are losing both their members and their influence. In the context of the fundamental and ongoing problem of non-compliance with freedom of association, workers are increasingly either legally prevented or de facto discouraged from joining a trade union, particularly with legislation allowing or encouraging the rise of new forms of work and contractual relationships - in a way which can be understood as "planned misery", as developed by Susan Marks. ${ }^{86}$ Workers may also not want to join existing unions because these may not target their specific needs raised by their (new) work situation. Another potentially problematic issue relates to the transformation of the identity of the worker. This is something that Maupain has pointed to when he describes workers as having several and sometimes conflicting identities (they may be at the same time workers, consumers, or pension shareholders, for instance). ${ }^{87}$ While this has to a certain extent always been the case, the contradictions that this situation raises have intensified in the contemporary period.

Employers in the ILO are also increasingly considered not to be fully representative of all employers, as the IOE has a limited membership. ${ }^{88}$ Moreover, similarly to trade unions, employers' organisations represent only a small spread of actual employers, which can for example vary from small enterprises to multinationals, with potentially clashing concerns. In Standing's words, most do not "represent either 'big capital' or 'petty capital', [or even] the

\footnotetext{
${ }^{83}$ Although this critique concerns employers just as much, if not more, it is often only levelled against trade unions (see Bhatt, 'A long was to go', in Visions of the Future of Social Justice, p.73; J. Klabbers, supra note 15, p. 185; J. Combacau and S. Sur Droit international public (Montchrestien, 2012) p. 729). Nolte and Lagodinsky argue, rightly, that representation issues are particularly acute with regards to indigenous people, the unemployed and migrant workers (Nolte and Lagodinsky, supra note 19, pp. 336-338).

${ }^{84}$ The PCIJ has specified in 1922 that a Workers' delegate represents all the workers in its Member State - the same goes for Employers’ delegates, who represent all employers (PCIJ, 1922, p. 23).

${ }^{85}$ Novitz and Syrpis, supra note 19, p. 375. The same is true of Employers.

${ }^{86}$ As Marks argues, "misery is planned insofar as it is informed by the logic of existing socio-economic arrangements-arrangements which, importantly, are themselves historically contingent and hence alterable” (S. Marks, 'Backlash: the undeclared war against human rights' (2014) 4 European Human Rights Law Review, pp. 325-326).

${ }^{87}$ Supra note 3, p. 367

${ }^{88}$ Standing, supra note 13, p. 373. Deborah France, presently Head of ACTEMP, explains that being dependant on the ILO, the IOE was seen as irrelevant by many Employers' organisations and almost disappeared before it decided to reform itself at the end of the 90s (D. France, 'Employers and the International Labour Organisation' in R. Blanpain and C. Engels (eds.), The ILO and the Social Challenge of the 21st Century (Kluwer Law International, The Hague, 2001) p. 62).
} 
millions of small-scale firms around the world" ${ }^{89}$ Furthermore, as Maupain also notes, within the context of the current global economy, in many ways power does not lie with 'employers' or 'entrepreneurs', but rather in the hands of bankers and financiers who act in the interest of shareholders. ${ }^{90}$

Critiques concerning representativity are certainly not new - they are persistent, enduring and widespread and the issues they raise cannot be overlooked. ${ }^{91}$ These issues are today to a large extent linked to broader economic processes variably referred to as 'neo-liberalism', 'globalisation', 'financialisation', 'deregulation', as well as more general issues of governance and development. ${ }^{92}$ The extent to which these changes make the operationalisation of tripartism and the ILO altogether irrelevant is debatable, however, especially in the absence of an alternative institution at the international level with additional legitimacy. Indeed, representing fully the diverse and fragmented nature of both capital and "new labour"93 has always been unrealistic. Some aspects of the conflict between capital and (new) labour are captured through the ILO’s constituents, however. Workers and Employers do represent real and conflicting general interests, and this has led to a range of initiatives, with a much broader reach than these organisations' particular interests, being adopted within the ILO (most ILS are after all, not only concerned with narrowly defined 'employees' but with all human beings who work). It is clear however that in view of the challenges faced, continuous efforts need to be put in place to improve formal representativity.

\section{B. Opening up the ILO to other actors?}

In the general context of the transformation of the world of work, there have been increased calls to give 'civil society' - the term is vague - and economic actors a more prominent role within the ILO. Civil society - beyond Employers and Workers organisations, of course - is not completely absent from the ILO: their consultation and participation in debates is provided for in the Constitution and Standing Orders of the, ${ }^{94}$ and some ILS make specific

\footnotetext{
${ }^{89}$ Standing, supra note 13, p. 379.

${ }^{90}$ Maupain, supra note 1, p. 10.

${ }^{91}$ See ILO, Director General Report, 2013, para.90.

${ }^{92}$ It is well understood here that the threat that these factors pose on labour rights, and more generally on human rights, is partly due to the response that governments have to them (e.g. A Clapham, Human Rights Obligations of Non-State Actors (OUP, Oxford, 2006) p. 5).

93 This expression is used here to reflect the understanding that the notion of 'labour', as understood by economists, has changed.

${ }^{94}$ Article 12(3) of the Constitution provides that the ILO "may make suitable arrangements for ... consultations ... with recognised [NGOs]” (around 150 NGOs have been granted observer status and are on a 'special list' see Art 2(4), Standing Orders of the ILC and the special list: http://www.ilo.org/pardev/civil-society/ngos/ilospecial-list-of-ngos/lang--en/index.htm - 462 representatives of international NGOs (many of which were
} 
reference to their involvement. ${ }^{95}$ Moreover, so-called 'Tripartite plus' meetings are quite frequent within the ILO in practice.

The need for clearer, greater and stronger participation by civil society has often been raised, however, not only by academics, but also by successive Director Generals of the ILO, not least by Albert Thomas in the 1920s. ${ }^{96}$ More recently, Michel Hansenne suggested to the ILC in 1994 that “the representatives of civil society within the Organization's policy-making organs should consider how best to enlist the cooperation and encouragement of all those who are willing to pursue the same goals using a similar approach", adding that it was "only with this cooperation that [the ILO] can really claim to be the social conscience of the United Nations". ${ }^{97}$ The Employers and the Workers at the time have however raised concerns that their constitutional role was being questioned in this regard. ${ }^{98}$ In 1999, the then Director General, Juan Somavia, taking note of its increasing importance worldwide, suggested to the ILC developing closer links with civil society. ${ }^{99}$ This was not well received by the constituents, however, and in 2002, a resolution concerning tripartism and social dialogue exceptionally instigated by both Workers and Employers - was adopted. While it noted the "valuable contributions of civil society institutions and organizations in assisting the Office in carrying out its work", it insisted on the need to "ensure that the tripartite constituents will be consulted as appropriate in the selection of and relationships with other civil society organizations with which the [ILO] might work". ${ }^{100}$ This effectively limited the autonomy of the Director General and the Office in matters related to civil society's involvement. ${ }^{101}$ The current Director General, Guy Ryder, attempted to open the door again in its 2013 report to the ILC, stating that "with the guarantees provided by improved tripartite governance

\footnotetext{
workers or employers NGOs) were present at the 2014 ILC); Art 18 of the Constitution provides for the presence of technical advisors appointed by the ILC in ILC Committees, and Art 56(8) of the Standing Orders of the ILC provides for their participation in debates, with permission. See also Art 1.10, Standing Orders of the Governing Body. As an example, associations of domestic workers were included in the debates preceding the adoption of a Convention on the topic in 2011. Generally, many NGOs work with trade unions. So called 'nonstandard' workers are represented by the ITUC - the Self Employed Women's Association (SEWA), is a member of the ITUC, for example.

${ }^{95}$ E.g. Convention No. 159 on Vocational Rehabilitation and Employment (Art 5) and Recommendation No. 200 on HIV/Aids.

${ }_{96}^{96}$ Albert Thomas attempted to give a formal role to cooperatives (Louis, supra note 17).

${ }^{97}$ ILO, 1994, p. 35.

${ }^{98}$ Maupain, supra note 3, p. 382

${ }^{99}$ See ILO, Director General Report, Decent Work, ILC, 97th session, 1999, p. 40.

${ }^{100}$ On this resolution, see in particular L. Baccaro and V. Mele 'Pathology of Path Dependency? The ILO and the Challenge of New Governance' (2012) 65 Industrial and Labor Relations Review, pp. 207-210. The efforts to involve NGOs failed for various reasons, according to Standing, revealing an "unholy alliance between the Workers and Employers in the Governing Body and inside the ILO" according to which each had incentives to maintain the status quo (Standing, supra note 13, p. 373)

${ }^{101}$ Baccaro and Mele, ibid., p. 209.
} 
processes in the ILO, it should be possible to involve non-tripartite constituents appropriately in the Organization's work, on the basis of clearly demonstrated advantage and well-defined roles" adding that these "can and do provide added value in terms of expertise and knowledge, and it serves no purpose to deny it or to forgo their contribution". ${ }^{102}$ While the reaction of the Employers was quite negative, ${ }^{103}$ the Workers stated that it was "open to considering innovative idea about the place of [NGOs]", ${ }^{104}$ including increasing their involvement in the ILO, however under "conditions" that they left undefined.

Similarly, when in 2013, the Director General presented the possibility that the Office might work directly with specific enterprises, the Employers' Group was very clear that "the ILO must be respectful of the Employers' Group”, that "the Office must therefore work on this issue with ... the Employers' Group” because “[h]ow the ILO does or does not engage with [their] members' companies [was their] business". ${ }^{105}$ Workers added that the ILO "should not engage with enterprises that were not willing to engage with trade unions". ${ }^{106}$ This issue was only resolved when ACTEMP and ACTRAV were given enhanced control in the engagement with the private sector. ${ }^{107}$

The resistance to providing for NGOs having a greater institutional role is understandable: inter alia, NGOs are not necessarily representative or independent either, their presence might create geographical imbalance, their lifespan is not necessarily very long, they are numerous, and their selection would not be straightforward. ${ }^{108}$ But there are of course vested interests in maintaining the status quo. The IOE exists only because of the ILO, ${ }^{109}$ and it might not want to see a change in its role. Trade unions on the other hand, might not want to experience a further loss of their influence. ${ }^{110}$ The boundaries and

\footnotetext{
${ }^{102}$ ILO, Director General Report, 2013, para. 98. The 2008 Declaration on Social Justice stated explicitly the need to cooperate with new actors (II.A)v)).

${ }^{103}$ ILO, Rec. of proc. No.7, 2013, p. 7/3.

${ }^{104}$ Ibid. p. $7 / 4$.

${ }^{105}$ Ibid. p. $7 / 3$.

${ }^{106}$ ILO, Draft minutes of the Governing Body, GB.320/INS/PV/Draft march 2014, para. 76

${ }^{107}$ ILO, GB.321/INS/6, June 2014.

${ }^{108}$ Maupain, supra note 3, p. 384 and ILO, Director General Report, 1999, 40. See also Charnovitz, supra note 4, 275-77 and Nolte and Lagodinsky, supra note 19, p. 325; L. Baccaro, 'Civil Society, NGOs, and Decent Work Policies: Sorting out the Issues’, Discussion Paper DP/127/2001, IILS, ILO.

${ }^{109}$ Bonvin, supra note 79, p. 69. Similar comments have been voiced about the ITUC on the workers' side Standing argues that the ILO "is one of the very few means by which to retain international legitimacy (and financial assistance for its members)” (supra note 13).

${ }^{110}$ Standing goes much further, arguing with regard to representativity in the Governing Body, that both Employers and Workers want "to retain their exclusive, monopolistic position and control the agenda with which they are most comfortable [and] each would support the other if any effort was made to broaden representativity" (ibid. pp. 379-380). Others have pointed out that some Employers and Workers members stay
} 
operationalization of tripartism will in any case not change without the agreement of the constituents. But things might be changing. Although a lot of resistance is still voiced by individuals on both sides, ${ }^{111}$ Workers may feel that in the present context, they need as much support as they can get from the labour movement beyond trade unions. ${ }^{112}$ Hoffer has voiced the opinion that there is a need to broaden "alliances of organizations and initiatives fighting for social justice and the rights and dignity of people in the world of work". Although this strategy would be "raise challenging and complex political questions", he argues however that, "as business as usual is no longer an option thinking the unthinkable might be a good start”. ${ }^{113}$ This change - or a change - might be brought about by the 2012 crisis, which may act as a catalyst for change. This crisis will be examined in the next section.

\section{Recent Developments}

Employers - and many Governments - in the ILO generally hold the opinion that (overly) regulating working conditions has adverse effects on economic growth, and this has been translated in a reticence to the idea of adopting new standards granting more protection to workers, ${ }^{114}$ in particular with regard to so-called 'non-standard' employment. ${ }^{115}$ At one level, this is of course a question of subjective ideological beliefs including as to the nature of economic model. At the same time, however, the regulation of labour issues can be linked to broader geopolitics. One of the main reasons that historically motivated the Employers and most Governments to support the adoption of ILS - the fear of Communism - disappeared with the fall of the Berlin wall. After the end of the Cold War, the tripartite groups 'unleashed' themselves from the role-playing that they had adopted and which allowed the West to offer a united front vis-à-vis the East. Indeed, in many ways, Employers effectively returned to their initial 1919 position, which Béguin describes as being “indifferent if not

\footnotetext{
on “well past their 'use by' date” and make little positive contributions (Creighton, supra note 73, p. 266). See also Maupain, supra note 1, p. 249. The Workers' Group has been addressing these issues however.

${ }^{111}$ Information obtained from interviews.

${ }^{112}$ Which is reported to be still very much alive (see eg. A. Chhachhi, ‘Introduction: The 'Labour Question' in Contemporary Capitalism’ (2014) 45 Development and Change, p. 899).

${ }^{113}$ F. Hoffer, 'When Very Little is Already too Much: The Struggle for International Labour Standards' in R. Sandbrook and A.B. Güven (eds.) Civilizing Globalization (SUNY Press 2014) p. 246. Frank Hoffer works in ACTRAV.

${ }^{114}$ See G. Rodgers et al., supra note 52, p. 24. Also, Sengenberger, supra note 75, p. 65.

${ }^{115}$ Although several instruments were adopted in the 1990s on key themes such as part-time work, homework, private employment agency, these have scarcely been ratified, and attempts to adopt an instrument on contract labour have failed. All workers remain covered by the more general conventions however. Moreover, the current discussions on a possible recommendation on formalising the informal economy fit very well into the current power struggle between Workers and Employers (see La Hovary, supra note, 67).
} 
openly hostile to the principle of international labour legislation”. ${ }^{116}$ This geopolitical development, which also took place in a context of ever-increasing neo-liberalism, has naturally led to tensions within the ILO and, as we have seen in the first part of this article, the scope for these tensions to have an impact on ILS and their supervision is extremely broad.

\section{The crisis of 2012 and its consequences}

As soon as the Berlin Wall fell, Employers in the tripartite CAS started to voice their disapproval regarding the independent CEACR 'expanding' ILS through its interpretations. ${ }^{117}$ This disapproval, which materialised specifically around the issue of the right to strike, initially remained very much within the CAS, and did not visibly affect its proceedings or those of other supervisory bodies. This long-standing disagreement escalated during the June 2012 ILC, however, when the Employers insisted that a disclaimer be added to the CEACR's annual report indicating that its work was not "an agreed or determinative text of the ILO tripartite constituents”. ${ }^{118}$ They moreover also refused to include any case that dealt with the right to strike in the list of ILS violation cases discussed each year within the CAS if such a disclaimer were not added. As the Workers refused to negotiate this list under such conditions, the CAS did not proceed to study any cases of violations in 2012, despite such an exercise being an intrinsic element of the ILO supervisory system since $1927 .{ }^{119}$ For most involved, the 2012 actions of the Employers in the CAS were clearly a surprise, even though the resistance of Employers, both within the ILO and generally, to the right to strike and its enforcement was well-known, both at the international and national levels. ${ }^{120}$ In fuelling this outcome, Employers escalated their negotiations tactics by not only rejecting the role that the CEACR has had in providing clarifications to ILS and the inherent nature of the right to strike to freedom of association (they thus attacked trade unions at their very heart, which will obviously weaken them further) but also paralysing the work of the CAS and breaking the precarious trust between Employers and Workers.

\footnotetext{
${ }^{116}$ Béguin, supra note 13, p. 7. The position of the IOE is that although there is a role for ILS, "the ILO is harming its credibility by continuing to adopt standards that are increasingly less ratified" (France, supra note 88, p. 63).

${ }^{117}$ This opposition was very reminiscent of a previous one during the Cold War period, when Socialist countries became "increasingly hostile" towards the ILO supervisory system when it criticized them (Ghebali, supra note 76, pp. 28 and 230-232). As Cox notes, the Director-General and some others in the Office "played a broker's role" in the resolution of this crisis (Cox, supra note 23, p. 107).

${ }^{118}$ ILO, Rec. of Proc. No 19(Rev.)/Part 1, 2012, para.150.

119 ibid para. 22.

${ }^{120}$ Information obtained from interviews.
} 
The crisis is not yet resolved. In 2013, amidst negotiations to find solutions, it was temporarily agreed to add to each conclusions of the CAS, when relevant, that it "did not address the right to strike ... as the employers do not agree that there is a right to strike recognized in Convention No. 87”; this led to further attacks on the CEACR because a clearly stated difference of opinion between the CAS and the CEACR "on such an important matter was detrimental to the Organization”. ${ }^{121}$ Despite intervention by the Governing Body in support of the supervisory mechanism, ${ }^{122}$ discussions surrounding the possible use of legal solutions provided by the Constitution, ${ }^{123}$ and the clarification by the CEACR of its mandate, ${ }^{124}$ the crisis intensified during the 2014 CAS and no conclusions were adopted in cases dealing with the right to strike. ${ }^{125}$ These developments, which have been studied elsewhere, ${ }^{126}$ obviously go well beyond the existence or not of a right to strike however and signal some changes in the practice of tripartism within the ILO as well as, necessarily, broader changes in the Organisation. These changes relate inter alia to the functioning and impact of ILO supervisory bodies, and the actions of the Office, and signal a break-down of trust between the parties and another stage in the way of doing business within the ILO with the Employers setting the terms. The post-Cold War indifference or resistance of Employers towards ILS has therefore developed into an additional opposition against the ILO supervisory bodies which, until now, they had not attacked in such a frontal manner. In turn, this means that their actions arguably have the potentially to play a larger role in the active shaping of ILS.

Several explanations can be put forward for the changing power play between Workers and Employers in the ILO. On the one hand, Employers have clearly increasingly felt in the

\footnotetext{
${ }^{121}$ CEACR Report 2014, para.14.

${ }^{122}$ Reaffirming inter alia that "in order to exercise fully its constitutional responsibilities, it is essential for the ILO to have an effective, efficient and authoritative standards supervisory system commanding the support of all constituents" (ILO, GB.320/LILS/4, para.40-43).

${ }^{123}$ Article 37 provides a legal answer to such deadlocks: Article 37(1) concerns referral to the ICJ for "any question of dispute" relating to the interpretation of the Constitution or of Conventions and article 37(2) concerns the setting-up of a Tribunal for matters related to the interpretation of Conventions. Resort to Art 37 needs to be decided by the Governing Body, through a vote or consensus; there was still no consensus at the Governing Body’s meeting in November 2014 on either paths, Employers and some Governments not favouring this avenue.

${ }^{124}$ CEACR, Report III (Part 1A), 2013 para. 33.

${ }^{125}$ Moreover, Employers questioned aspects of the application of Convention No 98 by the CEACR (see Croatia (ILO, Provisional Record, ILC, 103st Session, 2014, No.13(Rev) Part II/70-74).

${ }^{126}$ This crisis has been examined from different angles by a range of scholars, including J. Bellace, 'The ILO and the Right to Strike' (2014) International Labour Review; KD. Ewing, Myth and Reality of the Right to Strike as a 'Fundamental Labour Right' (2013) 29 IJCLLIR pp. 145-65; C. La Hovary, 'Showdown at the ILO? A historical perspective on the Employers group's 2012 challenge to the right to strike' (2013) 42 Industrial Law Journal, pp. 338-68; Maupain, supra note 74, pp. 117-65; L Swepston, 'Crisis in the ILO Supervisory System: Dispute over the Right to Strike’ (2013) 29 IJCLLIR pp. 199-218.
} 
post-Cold War period that they have a free hand to push for a deregulation of international labour law and for a reform of the ILO's supervisory system. This however is something which they arguably feel is extremely pressing as the potential for ILO supervisory bodies to have influence outside the ILO is changing - in particular, there are a growing number of initiatives taken outside the ILO, as well as judicial decisions, that make reference to ILS and/or the supervisory bodies’ pronouncements. ${ }^{127}$ On the other hand, however, Employers' organisations are (again) facing increasing disapproval from their members at the national level with regards to which ILS or which policies have been approved in the ILO. Certainly, the Employers' group has not always managed to block the initiatives they have opposed due to the ILO's tripartite decision-making structure, and this has had a cost on their credibility. ${ }^{128}$ This disapproval from national members might lead to decreases in membership, and difficulty in attracting new members, at a time when organisations need more members to survive - both from a financial and a legitimacy perspective. That being said, Workers realise now that they are also responsible for having let tripartism falter within the ILO. ${ }^{129}$

Although the Employers did reiterate "their full commitment" to both the ILO supervisory system and tripartism, ${ }^{130}$ they also stated that the ILO’s supervisory system as a whole is in "crisis", ${ }^{131}$ to the extent that the IOE explicitly called for a "change [to its] functioning""132 and is asking for a "holistic approach" to the "improvement of the supervisory body”. ${ }^{133}$ Yet, efforts to improve ILS and the supervisory bodies have been ongoing in the Governing Body, and a number of steps have already been taken in this regard. ${ }^{134}$ Moreover, at the same time as reiterating their commitment to tripartism, the Employers are also challenging established practices within the ILC, for example by

\footnotetext{
${ }^{127}$ See e.g. Maupain, supra note 74; C. La Hovary, 'The ILO’s Supervisory Bodies' 'Soft Law Jurisprudence', A Blackett and A Trebilcock (eds.) Research Handbook on Transnational Labour Law (Edgar Elgar, forthcoming, 2015).

${ }^{128}$ Information obtained from interviews.

${ }^{129}$ Ibid.

${ }^{130}$ ILC, Rec. of Proc. No. 13 Part I, 2014, paras. 11 and 228.

${ }^{131}$ ILO, Matters arising out of the work of the International Labour Conference, Governing Body, $317^{\text {th }}$ Session, 2013, GB.317/INS/4/1, para. 19-20.

${ }^{132}$ See IOE News Release, "Employers call for a change to the Functioning of the ILO Regular Supervisory System” (IOE, 2 February 2013).

${ }^{133}$ IOE, Discussing the "standards initiative": a holistic approach - A specific proposal with timeframe and objectives, 10 October 2014 http://www.ioeemorg/fileadmin/ioe_documents/publications/Policy\%20Areas/international_labour_standards/EN/_2014-1010 _G-641.R-102_A_holistic_approach_to_issues_in_the_ILO_Supervisory_System.pdf (consulted on 21 October 2014).

${ }^{134}$ See the ILS Policy and the documents adopted by the Governing Body's Committee on Legal Issues and International Labour Standards.
} 
suggesting that "consensus at all costs" in CAS reports is "no longer sustainable or credible”. ${ }^{135}$ However, as Workers have pointed out, "conclusions [are] meaningless unless they ha[ve] a tangible impact on the country concerned", ${ }^{136}$ and it is obviously difficult for conflicting conclusions to have such an impact. Moreover, agreeing to compromise and finding consensus is clearly an important aspect any meaningful social dialogue, which is what theoretically underpins CAS deliberations. Discussing social dialogue, Hyman argues that trust between the parties is especially important; ${ }^{137}$ yet, the events of 2012 have "nearly broken" confidence between the Employers and Workers within the ILO. ${ }^{138}$ This trust was clearly not been re-established during the 2013 or 2014 ILCs, and the question is therefore very much on what basis it will be restored, to the extent that it can be restored. ${ }^{139}$

Certainly, there is a widespread worry among Workers that Employers will simply continue attacking one thing after the other. ${ }^{140}$ As several individuals involved with the CAS for the Workers have remarked, historically the CAS has always been about finding compromises. Highlighting the importance of individuals in international organisations, they particularly point to the way that the previous spokesperson of Employers in the CAS (20052011), Ed Potter, an industrial relations specialist employed by Coca-Cola, while obviously defending the Employers' perspective, clearly believed in the necessity of promoting ILS and had always pursued a constructive dialogue. The Employers' new spokesperson in the CAS, Chris Syder, is a practising lawyer, and is seen to be clearly much less interested in compromising. His appointment has been perceived by the Workers as a 'game changer', a premeditated measure to increase the pressure on ILS. As one person put it, the fact that experts in industrial relations, who, despite holding very strong views about labour relations from an employer perspective were nevertheless looking for solutions, are being replaced by practising lawyers "is undermining tripartism”. ${ }^{141}$

This trend is spreading throughout the ILO supervisory bodies as Syder has now been elected as Employer Vice-Chairperson of the CFA by the Governing Body. The work of the CFA - which is behind many of the clarifications of the right to freedom of association and

\footnotetext{
${ }^{135}$ ILC, Rec. of Proc. No. 13 Part I, 2014, para.50. It should be added that consensus was not always the norm. ${ }^{136}$ Ibid., para. 209.

${ }^{137}$ R. Hyman, 'Social dialogue and industrial relations during the economic crisis: Innovative practices or business as usual?’ (2010) Working Paper No 11, Industrial and Employment Relations Department, ILO.

${ }^{138}$ ILO, Rec. of Proc. No. 19(Rev)/Part 1, 2012, para. 213.

${ }^{139}$ Information obtained from interviews.

140 Ibid.

${ }^{141}$ One in five Employer representative in the CAS is said to come from a company - the others all belong to law firms.
} 
collective bargaining including the confirmation of the right to strike in 1952 - will most certainly be severely affected by this development (both in terms of how issues are dealt with in the cases preliminary prepared by the Office and in terms of the discussions between the members of the CFA and the adoption of conclusions).

Another very direct consequence of this 'coup' by the Employers is that the CEACR has changed its practice as a result. Indeed, as the Workers remarked, the CEACR made more 'direct requests' in its 2014 report, which are a less visible and less accessible than 'observations' and are not the object of discussions in the CAS, and it has at the same time reduced the length of its observations. ${ }^{142}$ The Workers rightly expressed concern that the substance of the comments might be affected, and that this may contradict the supervisory and advisory functions of the CEACR. They expressed further concern that some cases were being deferred and they warned the effect of this "self-censorships" on Governments' feeling of impunity. ${ }^{143}$ The Employers on the other hand, noted these changes with satisfaction and "called on the [CEACR] to continue concentrating its report on the crucial compliance issues", ${ }^{144}$ when what is 'crucial' is of course relative. They claim that they have asked the CEACR to make these changes in order to enable more "room for inputs from constituents", arguing that this would "strengthen the credibility and acceptance of the supervision of ILO standards”. ${ }^{145}$

It is however difficult to understand how such changes would impact positively on a body which has the role of verifying in an independent manner the application of ILS in practice. Indeed, such changes will clearly profoundly affect the supervisory system - both in terms of its potential usefulness and possibly, its reputation. ${ }^{146}$ Until now, and despite many difficulties and criticism which will not be dealt with here, ${ }^{147}$ the CEACR offered an independent (or non-tripartite) view on the application of ILS at national level. While it is not inconceivable that the objectives of the ILO might be better pursued with the CEACR taking

\footnotetext{
${ }^{142}$ ILC, Rec. of Proc. No. 13 Part I, 2014, para. 67.

143 Ibid. para. 67.

${ }^{144}$ Ibid. para. 57.

${ }^{145}$ Ibid. para. 55. At the Employers' request, the CEACR met with the Worker and the Employer's Chairperson before its meeting, in an unprecedented move (ILO, CEACR Report, 2013, para.10). As a result, the Experts declared that "some adjustments been made" as to the length and the presentation of information to the 2014 CEACR report (see CEACR 2014 (I), para. 26).

${ }^{146}$ The events of 2012 have been brought to the attention of national and international courts to dispute the CEACR's work (see e.g. RMT v. United Kingdom (Application No 31045/10), 8 April 2014, para. 69 - while the ECtHR stated that it was not reconsidering the CEACR's "role as a point of reference and guidance for the interpretation of certain provisions of Convention No 87" - it did not, however, apply the CEACR's jurisprudence on sympathy strikes, which are crucial in a globalised world).

${ }^{147}$ La Hovary, supra note 126, pp. 345-46 for a summary.
} 
on different roles and practices, ${ }^{148}$ reform of the Organisation's supervisory system has until now always been undertaken within the Governing Body, in a way that respects the views of all. By taking unilateral action, the Employers clearly risk reducing the legitimacy, impact, visibility and coherence of the supervisory system (which is likely to be their objective).

Further effects might be felt within the Office. Indeed, the Office, or part of it, has become extremely aware of the need to keep the constituents content and its attitude has certainly changed over the years in this regard (see above). Certainly, the Office traditionally held a "leadership role in promoting the objectives of the ILO" and officials considered themselves as "collaborators in the pursuit of social justice", ${ }^{149}$ with the Director-General in particular having substantial powers. These role, powers and scope of action have all been receding over the years for various reasons. The accusations of Employers that the Office was not neutral when it contributed to the CEACR reports - the important role of the Office in this regard has never been a secret ${ }^{150}$ - will only make the Office even more cautious. Certainly, the times when Director Generals either “controlled” or “ignored” ILO constituents are gone, ${ }^{151}$ but it is clear that a strong Office, acting as a 'broker' as it did during the Cold War, would help resolve this crisis. So far, it has been extremely difficult to bring the groups to compromise.

Ultimately, though, this may only be at best a rearguard action. The processes described above have been the product of broad shifts in global geopolitics, not just in ideological terms, but also the rise of new nation-based configurations of power. On the one hand, as Sengenberger remarks, the rise of some regions over others has translated in much more vocal and proactive representatives of developing countries in the ILO. ${ }^{152}$ On the other hand, this shift has also allowed Employers to be more vocal in their demands, as the rising powers may be generally less inclined to social regulation, ${ }^{153}$ and States are not taking the side of Workers as they used to. ${ }^{154}$ Furthermore, the events shaking the ILO are happening in a

\footnotetext{
${ }^{148}$ Maupain has suggested a re-balancing of the available means of supervision (supra note 74).

${ }^{149}$ V. Leary, 'Lessons from the Experience of the International Labour Organisation', in P. Alston (ed.) The

United Nations and Human Rights: a Critical appraisal (Clarendon Press, Oxford, 1992) p. 613.

${ }^{150}$ See CAS 2012 para.153. Cox, supra note 23, p. 112; Creighton, supra note 73, p. 261.

${ }^{151}$ Information obtained from interviews.

152 Sengenberger, supra note 75, p. 63. This was manifest in the 2011 discussions of the Convention No. 189 on Domestic Workers. Generally, Sengenberger points out to the fact that "the ILO framework of international governance may be said to be more democratic and more up - to - date with the distribution of the present economic and political weight in the world than the system of governance of the international financial institutions" (ibid).

${ }^{153}$ Maupain, supra note 1, p. 59.

${ }^{154}$ Haas, for example, argued that while historically some Governments were likely to take the side of the Workers (Haas, supra note 50, p. 213; also Landelius, supra note 21, p. 522), the State is now supporting
} 
broader context where States have been losing control over the issues dealt within the ILO, some more willingly than others, making their intervention to restore a fair balance within the ILO more difficult. ${ }^{155}$

\section{Conclusion}

This article has explored the fundamental place tripartism holds in the ILO's functioning, highlighting the multiple challenges posed by its operationalisation. In particular, it has examined the way that tripartism intervenes at all levels of the ILO, including especially its central role in the adoption of ILS, their implementation and their supervision. It has also explored the difficulties that tripartism has always faced in practice, including contingent ones that have changed over time, as well as more intractable ones such as the concerns surrounding the representativity of constituents groups. This latter issue, which relates to the difficulty of representing the conflicting and fragmented interest of workers and employers, has been a major object of concern and criticism. At the same time, while there is a clear need to improve the operationalisation of tripartism, including for example to take into account the voice of other actors in the 'world of work' beyond Trade Unions and official Employer organisations, implementing any change in the ILO is extremely difficult in view of the vested interests of the actors in place. The urgency to reinforce the scope of representativity and legitimacy seems to require action on the Workers side, however, as Employers have clearly less immediate incentive to do so despite the issue also targeting them.

Having said this, the crisis currently shaking the very foundations of tripartism within the ILO (the search for compromise through good faith and dialogue) may well precipitate a transformation of the system (although the direction this transformation might take is another matter). On the one hand, this crisis, which escalated around the issue of the existence of a right to strike and the mandate of the CEACR to interpret such a right when it is not explicit in a convention, reflects a deep break-down of trust between Employers and Workers within the ILO. On the other hand, the crisis has also revealed a much deeper dissatisfaction with ILS and their supervision. Both the supervision of ILS and the right to strike touch upon fundamental concerns of the ILO, and the crisis needs to be resolved. The statu quo ante is clearly not an option considering that the Employers have strongly voiced their view that the

capital. It can certainly be contended that it has abandoned its mediating role between capital and labour (Chhachhi, supra note 112, p. 902). Information also obtained from interviews.

${ }^{155}$ Information obtained from interviews. 
situation needs to change, however. Recent events have illustrated how despite States formally having more power than Workers and Employers within the ILO, ${ }^{156}$ the latter two institutions actually have the necessary leverage to influence and even change the course of the ILO. This is however especially the case when one constituent is in a position of strength vis-à-vis the other, as is currently true of Employers vis-à-vis Workers.

The end of the Cold War, and the rise of neo-liberalism as a dominant global ideology, revealed the extent to which tripartite consensus was linked to the ILO's origins as a bulwark against communism. Once this threat receded after 1989, maintaining common objectives among the ILO constituent groups that went beyond their own particular interests has clearly proven to be difficult, and the necessity for the Organisation's ILS to be backedup by its current supervisory system has been undermined (the mere fact that this crisis is ongoing is already arguably negatively affected both the ILO and its supervisory system). This latter issue is fundamental and will inevitably entail a repositioning of the constituents within the ILO. This repositioning however needs to be done in a way that respects the Constitution's premises and principles, including first and foremost the core mission to pursue "social justice" and the famous motto that "labour is not a commodity". This principle, which seems at times forgotten and relegated to lofty ideals, should be of central concern in our contemporary times of economic crisis and inequality; indeed, it is not out of the question that the initial role of the ILO as a 'revolution insurance' comes to the fore again. Whether and how the ILO or a different organisation yet to be created - considering that the ILO's capacity to deal effectively with the world of work is continuously being diminished - will take up this challenge once again remains to be seen.

Having said this, this crisis also suggests that the ILO does matter, as does its supervisory system, otherwise the Employers would not have bothered to attack it to change it. In this respect, perhaps we should start from the fact that commitments to tripartism are regularly reiterated on paper. As is stated in the ILO's Declaration on Social Justice, adopted unanimously by the tripartite constituents of the ILC in 2008, social dialogue and tripartism are the most appropriate methods for, inter alia "translating economic development into social progress, and social progress into economic development; facilitating consensus

\footnotetext{
${ }^{156}$ Indeed, Governments have half the votes compared to a quarter each for Employers and Workers in plenary meetings and they are the only constituents empowered to vote on the ILO's budget, which they finance. They are moreover the only constituents directly consulted by the Office during the preparation of ILS - ILS are addressed to them, although the procedural rules provide they do need to consult Employers and Workers - and they nominate the Workers and Employers representatives to the ILC (Haas, supra note 50, p. 213), which under the Constitution are to be the "most representative" in the country.
} 
building on relevant national and international policies that impact on employment and decent work strategies and programmes; and making labour law and institutions effective ...”. Although the operationalization of tripartism at the international level has posed, and continues to pose, important difficulties, as a previous Director-General of the ILO argued, it is "a precious institution", ${ }^{157}$ which is a unique feature of the ILO, and as such, should not be discarded precipitously. There is no doubt that tripartism "is only as valuable as it is effective", 158 but the onus should very much be on reforming and improving a system that has proven its worth for almost 100 years now rather than letting it become irrelevant. This is all the more so considering that any multilateral organisation concerned with labour issues and social justice must clearly be able to represent more than a single interest, and in this respect, no better solution than tripartism has come to the fore.

${ }^{157}$ ILO, Report of the Director-General (Part I), Defending values, promoting changes, ILC, $81^{\text {st }}$ session, 35 ${ }^{158}$ Ibid. 